\title{
PKB/Akt kinase localization and role in stemness maintenance in cancer
}

\author{
Mayur Vilas Jain
}

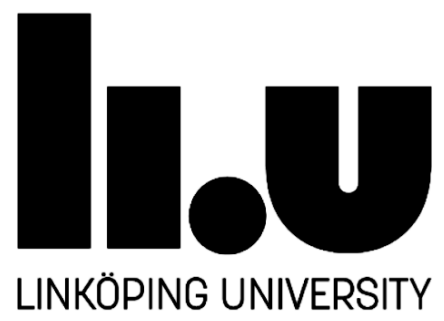

Division of Cell Biology

Department of Clinical and Experimental Medicine

Faculty of Medicine and Health Sciences

Linköping University, SE-581 85 Linköping, Sweden

Linköping 2016 
Copyrights $\odot$ Mayur Vilas Jain, 2016

ISBN 978-91-7685-806-6

ISSN 0345-0082

All previously published articles have been reprinted with the permission of the publisher.

Printed by Liu-Tryck, Linköping, Sweden 2016 
To my Mother.

"You may never know what results come of your action, but if you do nothing there will be no result"

-Mohandas Karamchand Gandhi 
Supervisor

Karin Roberg, Adjunct Professor

Dept. Clinical \& Experimental Medicine

Otorhinolaryngologi, Linköping University, Linköping, Sweden

Co-supervisor

Piotr Religa, Associate Professor

Department of Medicine

Karolinska Institutet, Stockholm, Sweden

Mehrdad Rafat, Assistant Professor

Department of Biomedical Engineering

Linköping University, Linköping, Sweden

Faculty opponent

Mahvash Tavassoli, Professor

Department of Mucosal and salivary biology

King's College London Guy's Hospital, London, United Kingdom

Board committee

Xiao-Feng Sun, Professor

Department of Clinical and Experimental Medicine

Linköping University, Linköping, Sweden

Olle Stål, Professor

Department of Clinical and Experimental Medicine

Linköping University, Linköping, Sweden

Christopher Barker, Docent

Department of Molecular Medicine and Surgery

Karolinska Institutet, Stockholm, Sweden

\section{Funding}

This work was supported by the funding from Cancerfonden, Integrative Regenerative Medicine center (IGEN) and core/startup support from

Linköping University. 


\section{Table of Contents}

Abstract ................................................................................ 6

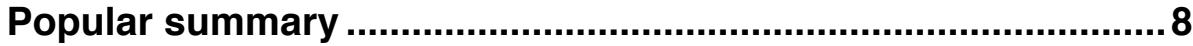

List of publications......................................................................... 10

Abbreviations...............................................................................11

Introduction..................................................................................13

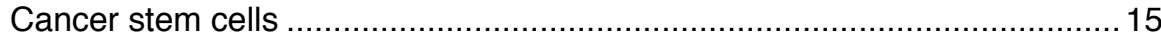

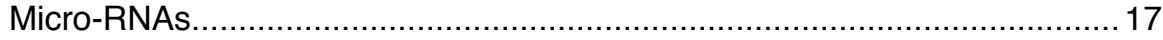

PI3K-Akt pathway .......................................................................... 20

Nuclear Akt ............................................................................. 24

Luminescent conjugated oligothiophenes (LCOs) ................................... 25

Material and methods..................................................................29

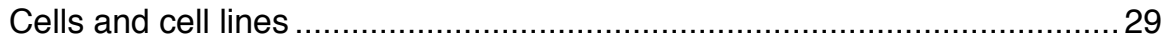

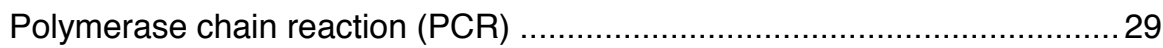

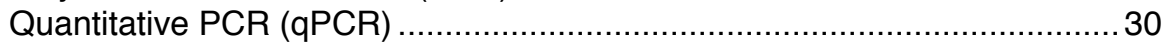

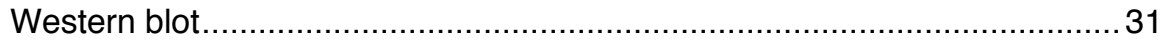

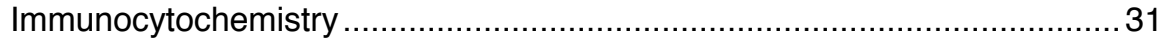

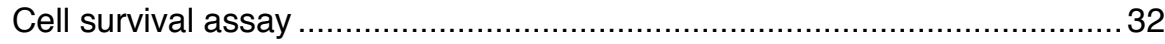

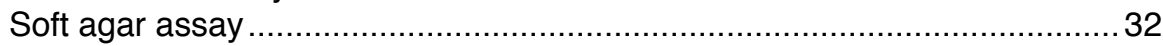

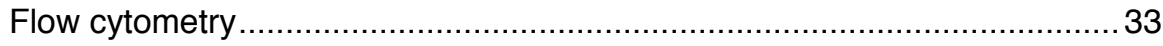

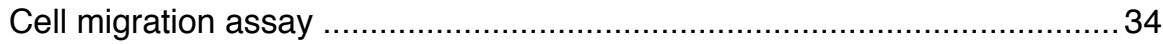

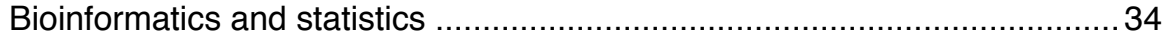

Paper 1: Cell type-related differences in staining with pentameric thiophene derivatives..................................................................................... 35

Paper 2: Nuclear-localized Akt enhances breast cancer stem-like cells

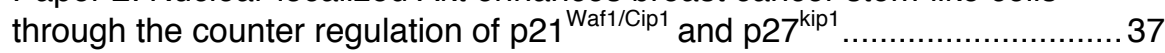

Paper 3: Inhibition of miR301 enhances Akt-mediated cell proliferation by accumulation of PTEN in the nucleus and affects cell-cycle regulatory

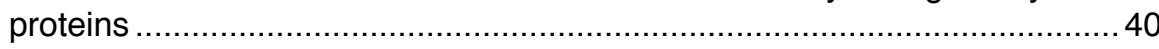

General Discussion ............................................................ 43

Future perspectives .................................................................... 47

Acknowledgements.................................................................. 48

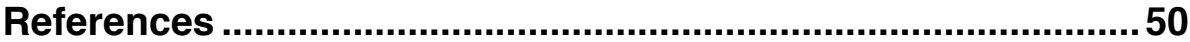




\section{Abstract}

Cancer incidence rates have increased over the last decade. Currently available therapies are only moderately effective in targeting cancer cells. Established cancer treatment protocols fail to eliminate populations of cancer stem cells (CSCs), which develop resistance against the chemotherapeutic drugs and lead to cancer recurrence. Therefore, understanding the mechanisms by which CSCs resist drugs and identifying molecular markers are both necessary to further improve prognosis and to develop new treatment strategies. Increased protein kinase B/Akt1 gene expression and/or activity have been found increased in majority of cancer types. Akt1 is a key player in PI3K-AktmTOR pathway that is vital for cell survival, proliferation, migration, invasion, metastasis, angiogenesis and apoptosis. In this study, we investigated a series of novel markers to improve the characterization of CSCs, with particular focus the roles of Akt in CSC maintenance and the regulatory role of micro-RNA (miR) in cancer cells. While utilizing in breast cancer cells as models, we found that luminescent conjugated oligothiophenes (LCOs), p-HTMI and p-HTAA have the potential to differentially stain various subpopulations of cancer cells, presumably also CSCs among breast cancer cells. However, further studies are needed to confirm these results. Additionally, when we investigated the effect of Akt intracellular compartmentalization on CSC development, the results revealed that nuclear Akt enhances CSC proliferation (ALDH ${ }^{+/ \text {High }} \mathrm{CD} 44^{+/ \text {High }} / \mathrm{CD} 24^{-/ L o w}$ ) and clonogenicity, which was counter examined and confirmed by using the Aktspecific inhibitor triciribine. Furthermore, while investigating the impact of Akt on miR regulation in cancer cells, we found that Akt overexpression decreased 
miR301 expression in cancer cells. The decreased miR301 expression led to enhanced cell proliferation and migration and this correlated with the accumulation of PTEN in the nucleus. In conclusion, our data suggest that LCOs may have the potential to serve as a CSC marker. The enhancement and development of CSCs might be controlled by the intracellular localization of Akt, and the novel miR301 has an inhibitory potential towards PI3K-Akt pathway. Thus, this extensive study on CSCs and their relation to the PI3K-Akt pathway could provide a platform for developing novel chemotherapeutic drugs and modifying the targets of currently available drugs for cancer treatments. 


\section{Popular summary}

Cancer is one of the rapidly growing diseases worldwide and it has been reported that 8.2 million people die every year due to cancer. Currently, surgery, chemotherapy and radiotherapy are the only available treatments to fight against cancer. However, cancer recurrence is the prevailing problem as current treatments target only the mature cancer cells and not cancer stem cells (CSCs). CSCs are a subpopulation of cancer cells which possess similar properties like self-renewal and differentiation which causes tumour initiation and cancer recurrence. The mechanism by which CSCs are being resistant to the currently available anti-cancer drugs is still not clearly understood.

The expression of the gene, protein kinase B/Akt1 has been found to be increased in majority of cancers. Akt1 is a key player in the cell signaling pathway PI3K-Akt-mTOR which is vital for cell survival, proliferation, migration, invasion, metastasis, angiogenesis and apoptosis. Thus, in this study, we have investigated the role of Akt in CSC development and micro-RNA regulation in cancer cells and also to find an improved characterization strategy of CSCs using a series of novel markers. We have found that luminescent conjugated oligothiophenes (LCOs) have potential to stain a rare-population of cells (CSCs) from the breast cancer cells. Further, when we have evaluated the effect of Akt intracellular localization on CSCs development, we have found that nuclear localized Akt enhances CSCs proliferation $\left(\mathrm{ALDH}^{+/ / \text {High }} \mathrm{CD} 44^{+/ / \text {igh }} / \mathrm{CD} 24^{-/ L o w}\right)$ and when we increased the Akt level, we have found decreased miR301 expression that leads to enhanced cell proliferation and migration. 
In conclusion, our study suggests that LCOs could serve as a potential marker for CSCs. Intracellular localization of Akt controls CSCs enhancement and development. The novel miR301 has an inhibitory potential towards PI3KAkt pathway restricting cell proliferation. Thus, this detailed study of CSC characterization and biology could provide a platform to develop novel chemotherapeutic drugs and modify the targets of currently available drugs for improved cancer treatment. 


\section{List of publications}

Included in the thesis

1) Cieslar-Pobuda A, Back M, Magnusson K, Jain MV, Rafat M, Ghavami $S$, Nilsson KP, Łos MJ. Cell type related differences in staining with pentameric thiophene derivatives. Cytometry Part $A$ : the journal of the International Society for Analytical Cytology. 2014 Jul;85(7):628-35.

2) Jain MV, Jangamreddy JR, Grabarek J, Schweizer F, Klonisch T, CieślarPobuda A, Łos MJ. Nuclear localized Akt enhances breast cancer stemlike cells through counter-regulation of p21(Waf1/Cip1) and p27(kip1). Cell cycle. 2015;14(13):2109.

3) Jain MV, Shareef A, Likus W, Cieslar-Pobuda A, Ghavami S, Los MJ. Inhibition of miR301 enhances Akt-mediated cell proliferation by accumulation of PTEN in nucleus and its effects on cell-cycle regulatory proteins. Oncotarget. 2016 Mar 8. 


\section{Abbreviations}

\begin{tabular}{ll} 
CSCs & Cancer stem cells \\
ROS & Reactive oxygen species \\
ALDH1 & Aldehyde dehydrogenase-1 \\
miRs & Micro-RNAs \\
RISC & RNA-induced silencing complex \\
PI3K & Phosphatidylinositol-3-kinase \\
TRKs & Tyrosine receptor kinases \\
GPCR & G protein-coupled receptors \\
PTEN & Phosphatase and tensin homolog \\
PKB & Protein kinase B \\
PH & Pleckstrinhomology \\
PDK & Phosphoinositide-dependent kinase \\
mTOR & Mammalian target of rapamycin \\
TSC & Tuberous sclerosis complex \\
PRAS40 & Proline-rich Akt substrate 40 \\
Bcl2 & B-cell lymphoma 2 \\
MDM2 & Murine double minute 2 \\
CDK & Cyclin-dependent kinase \\
GSK3 & Glycogen synthase kinase-3 \\
NLS & Nuclear localization sequence \\
TCL1 & T-cell leukaemia-1 \\
LCOs & Luminescent conjugated oligothiophenes \\
p-HTAA & Pentameric hydrogen thiophene acetic acid \\
h-FTAA & Heptameric formyl thiophene acetic acid \\
MDBs & Mallory-Denk Bodies \\
HeLa & Henrietta Lacks \\
PCR & Polymerase chain reaction \\
dsDNA & Double-stranded DNA \\
SDS-PAGE & Sodium dodecyl sulphate-polyacrylamide gel \\
PVDF & electrophoresis \\
& Polyoride \\
\hline
\end{tabular}


ICC

MTT

7-AAD

T-ALL

WT

CKIs
Immunocytochemistry

3-(4,5-Dimethyl-2-thiazolyl) 2,5-diphenyl-2H tetrazolium bromide

7-Aminoactinomycin D

T-cell acute lymphoblastic leukaemia

Wild type

Cyclin-dependent kinase inhibitors 


\section{Introduction}

Some of the earliest evidence of cancer among humans was found in ancient manuscripts of Egyptian mummies. The word "cancer" originates from the ancient Greek word "karkinos", which was used to describe carcinoma tumour cells and was coined by the great physician Hippocrates of Kos (ca. 460$360 \mathrm{BC})(1)$. According to the GLOBOCAN 2012 estimates of cancer incidence worldwide, 14.1 million newly diagnosed cases of different types of cancer and 8.2 million cancer-related deaths are recorded per year. Apart from that, 32.6 million people throughout the world have been shown to be living with cancer (2).

Cancer seems to be evolving in a Darwinian manner for survival via harsh strategies in order to withstand such challenging environments as acidosis, hypoxia and anticancer immune responses (3). It is likely that the adaptation of cancer to the evolution process considerably contributes to the development of tumours that are able to metastasize to other organs and are resistant to toxic therapies (4). Currently, there are 27 major types of cancer; all types of cancer cells grow abnormally, divide, re-divide, and escape the cell death stage of the cell cycle process (5).

The main causes of cancer formation are environmental and lifestyle factors, as well as genetic and epigenetic alterations. Lifestyle factors, including smoking, alcohol consumption and diet are important universal risk factors responsible for causing cancer (2). Environmental factors, including viral (e.g., human papilloma virus) and bacterial (Helicobacter pylori) infections, account for $10 \%$ of tumours in developed countries $(6,7)$. Genetic (e.g., mutation, translocation and polymorphism) and epigenetic (e.g., DNA methylation, histone 
modification and loss of imprinting) alterations drive cancer by affecting the function and structure of the genome. Disruptions of gene expression patterns can lead to abnormal activity and overexpression of protein, which deregulates the transcriptional regulation mechanisms of oncogenes and tumour suppressor genes. These alterations are in general inheritable at the cellular level, thus contributing to the clonal expansion of cancer cells (8). During cancer progression, somatic mutations appear and accumulate, allowing the cancer cells to proliferate much faster than normal cells in an uncontrolled manner. This property of cancer cells leads to faster progression of tumour tissue relative to normal tissue (9). Somatic mutations can lead to defects in cell cycle regulation, apoptosis, and the DNA repair and genomic stability $(10,11)$.

Intriguingly, decades of cancer research suggest that deregulation of several physiological functions contribute to developmental processes, e.g., cell proliferation, differentiation and survival specifically contributes to different types of cancer. Deregulation of all those physiological functions during cancer development is well illustrated as "hallmarks of cancer", as proposed by Hanahan and Weinberg in 2000; these were recently updated, with the addition of new characteristics. The proposed characteristics of cancer are the following: inhibition of cell death; enhanced angiogenesis; uncontrolled growth; insensitivity to growth suppressors; activation of invasion and metastasis; enabling replicative immortality by escaping immune destruction; deregulated cellular energetics; tumour-promoting inflammation and genome instability; and mutations $(12,13)$.

The choice of available cancer treatments is dependent on several factors, such as cancer type, location, stage, mutations and recurrence. The 
types of available treatments for cancer can be categorized as surgery, chemotherapy, radiotherapy or targeted therapy. Standard chemotherapy is an important part of treating cancer and is often used in combination with radiation. Large number of chemotherapeutic drugs has been developed. For e.g., Cisplatin, a platinum-containing compound that interacts with DNA, which lead to the activation of cell-cycle arrest and DNA repair $(14,15)$. However, these drugs have several limitations due to a lack of selectivity for tumour cells over normal cells, resulting in insufficient drug concentration in tumour cells, systemic toxicity and cancer recurrence due to drug-resistant cancer cells (16). Targeted therapies involve the targeted delivery of toxic substances to specifically destroy cancer cells (17). Targeted therapy involves the use of monoclonal antibodies, e.g., Herceptin (18), or small oral drugs, e.g., Imatinib (19), which ultimately block cancer cell proliferation, survival, and promote cell cycle arrest, or induce cell death (17). The application of radiotherapy depends on type, stage and localization of tumour. Primary resectable tumours are often treated with 25 Gy in 5 fractions, whereas primary non-resectable tumours are treated with 50 Gy in 25 fractions (20). Radiotherapy is largely recognized to cause DNA damage via high-energy photons and free radicals produced adjacent to DNA. DNA damage includes base/sugar damage, as well as single-strand and doublestrand breaks (21).

\section{Cancer stem cells}

Cancer stem cells (CSCs), also called as 'cancer-initiating cells' or 'cancer stem-like cells', are a subpopulation of cancer cells. They possess properties 
similar to those of normal stem cells, such as asymmetric cell division, selfrenewal and differentiation. CSCs can originate from the transformation of normal stem cells and undergo epigenetic alterations that give them capability for self-renewal and to drive tumourigenesis $(22,23)$. Epigenetic alterations in DNA, histones, and non-coding RNA and miRNA cause modifications in the resulting gene expression. These alterations in the epigenome determine the specific fate and mechanism for the tumorigenic-reprogramming of these cells. These alterations are not as stable as mutations and can be reversed. However, some types of alterations remain stable, which lead to the formation of CSCs with distinct changes in cellular function (24).

The first evidence of CSCs was found in breast cancer, and it has been shown that as few as 100 cells $\left(C D 44^{\text {high }} / C D 24^{\text {low }}\right)$ could form a tumour when injected into mice (25). Other studies, for example conducted using stemness markers conjugated, or coexpressed with fluorescent proteins, for lineage tracing, confirmed that these clonal cells act as CSCs by giving rise to malignancies and showing resistance to anti-cancer drugs (26-28). Later on, CSCs were found to be present in different types of cancer, e.g., brain (29), colon (30), pancreatic (31), head and neck (32) and prostate cancer (33).

The presence of CSCs might explain why cancer can recur after treatment. Most anti-cancer drugs (i.e., chemotherapeutics) only act on 'mature' cancer cells; while these cells are damaged by such drugs, CSCs appear to be resistant to conventional therapies and become responsible for the relapse of most cancers (34). In many instances, it has been shown that CSCs have elevated ATP-binding cassette levels, which promotes drug resistance (35). In 
glioma, CSCs preferentially activate DNA-damage checkpoints, allowing them to repair damage faster and escape radiation-mediated cell death (36). In breast cancer, CSCs maintain low level of reactive oxygen species (ROS) mediated by higher expression levels of free radical scavengers, which ultimately causes radiotherapy resistance (37). Disruption of cell cycle inhibition may also contribute to cancer stem cell proliferation (38).

Different studies have shown that CSCs are the major cause for development of breast and other types of cancer. Hence, CSCs need to be targeted for treatments to be effective $(22,25,39)$. Breast cancer stem-like cells could be isolated by using surface markers, such as aldehyde dehydrogenase- 1 (ALDH1), which is enriched in CSCs (40). Several studies have shown that different signalling pathways play various significant roles in CSC biology. It has been reported that alterations in signalling pathways, such as Notch, Wnt and Hedgehog, are important in normal stem cells; these alterations might play key roles in the maintenance of CSCs (41). Several non-coding RNAs, e.g., microRNAs (miRs), also play important roles in cancer biology.

\section{Micro-RNAs}

Micro-RNAs are small, non-coding RNAs that are key cellular elements in both normal and diseased conditions. Over the last decade, miRs have become a new tool for defining developments in many human pathologies (42). The first miR, Lin-4, was discovered in 1993 in studies on Caenorhabditis elegans. Lin-4 acts via the Lin-14 3'UTR to inhibit the translation of Lin-14 mRNA (43). In mammals, miRs are predicted to control the activity of approximately $50 \%$ of all 
protein-coding genes. A miR is processed in the nucleus from the transcription of primary miR by RNA polymerase II, forming a typical hairpin structure. Then, the microprocessor complex comprising DGCR8 and the RNAse enzyme Drosha trims the primary miR to precursor miR (pre-miR) hairpin. The pri-miR is then exported to the cytoplasm by a protein known as exportin 5 . In the cytoplasm, a protein complex, including Dicer and TRBP, further trims the stem loop of the pre-miR to produce a short, double-stranded RNA molecule. Next, AGO2 protein interacts with DICER to bind the miR, which causes the dsmiR to unwind, releasing single-stranded RNA. The remaining strand interacts with AGO2 protein and GW182 to form an RNA-induced silencing complex (RISC). This mature miR complex uses predominantly $3^{\prime}$ ' UTRs to target complementary miR sequences and may induce multiple post-transcriptional gene silencing by cutting the mRNA or by inhibiting the translation process $(44,45)$.

The importance of miR in cancer has been underlined by controlling the expression of target mRNA to facilitate carcinogenesis (42). Whether a miR functions to promote or suppress cancer depends on the direct target genes. Breast cancer promoters miR155 (46), miR21 (47), and miR300 (48) and suppressors miR7 (49), miR16 (50), and miR30a (51) have both been previously described and demonstrated. Thus, miRs play a major role in all types of cancer which is one of the hallmarks defined by Hanahan and Weinberg (13).

Recently, miR301 has attracted much attention due to its significant contribution to different biological processes, including cell differentiation, proliferation, survival, and apoptosis in pancreatic (52), hepatocellular (53), lung, colorectal (54)and breast cancer (55), as well as sickle cell disease (56). Several 
miRs target signalling molecules, such as TGF- $\beta$, Wnt, EGF and Akt, and they serve as nodes for signalling pathways that regulate central cellular processes, such as cell survival, proliferation, transcription, translation, differentiation and metabolism, as well as the cell cycle (57).

miRs can act as markers of the prognosis of pathological conditions. Our understanding of molecular alterations underlying cancer has created opportunities for more effective and accurate treatment and better diagnosis. A new era of enhanced personalized medicine choices depends on molecular analyses, such as DNA methylation, gene expression and miR expression. miRs have been shown to yield essential information and have greater utility than mRNAs as prognostic indicators (58). miR expression in cancer frequently reflects the development and origin of the cancer type. A blinded study with 400 tumour samples from 22 different types of tumours showed that miR expression classified the cancer type according to tissue of origin with greater than $90 \%$ accuracy (59). Therefore, many clinical trials consider miRs as biomarkers for disease prognosis, drug efficacy, and patient satisfaction. Despite the challenges in the miR delivery systems, there are currently two clinical trials for miR-based treatments, the first-ever of which uses miR34a. This molecule interacts with 24 known oncogenes. The MRX34a is a synthetic miR34a mimic that was loaded into liposomal nanoparticles for efficient delivery. MRX34a is currently in a phase I clinical trial for lung cancer (60). Another clinical trial is testing Miravirsen (miR122) for hepatitis $C$ therapy (61). Miravirsen is complementary in sequence to miR122 and has a modified, locked nucleic acid structure, which protects against degradation and improves its target affinity (62). 


\section{PI3K-Akt pathway}

Phosphatidylinositol-3-kinase (PI3K) came into the focus of cancer research in the mid-1980s, when it became apparent that PI3K activity was physically and functionally associated with the transforming activity of viral oncogenes (63). PI3K-Akt signalling pathway activation is vital to many aspects of control over the proliferation and survival of various normal and cancer cell types. Hence, its hyperactivity may contribute to aggressive cancer growth, metastatic capacity and chemotherapeutic resistance (64).

The PI3K-Akt pathway is downstream of many signalling cascades, including tyrosine receptor kinases (TRKs) and G protein-coupled receptors (GPCR). It is up-regulated in several types of cancer (65). The major reason for the hyperactivation of the PI3K-Akt pathway is the inactivation or mutations of the tumour suppressor gene phosphatase and tensin homolog (PTEN) (66). PTEN is a central negative regulator of PI3K-Akt signal transduction that is responsible for the dephosphorylation of $\mathrm{PI}(3,4,5) \mathrm{P} 3$ and inhibition of downstream signals (67). Although PTEN has a well-defined function in the cytoplasm, under certain circumstances, it has also been found in the nucleus. The nuclear function of PTEN is not clearly understood, but its role in the nucleus could be in opposition to its cytoplasmic function (68).

PI3K is a large and complex protein family that comprises three classes with different subunits and isoforms. Only class I PI3Ks will be discussed in this thesis because of the contextual relationship to other topics of the thesis(69). PI3K consists of a catalytic subunit (P110) and an adaptor/regulatory subunit (P85). Both form a heterodimeric complex, which is activated either through 
receptor conformational changes or by RTK and GPCR $(70,71)$. The cytosolic $\mathrm{PI3K}$ are responsible for the phosphorylation of the inositol ring of $\mathrm{PI}(4,5) \mathrm{P} 2$ at the $3^{\text {rd }}$ position, creating $\mathrm{PI}(3,4,5) \mathrm{P} 3$, which is a potent secondary messenger (72). This function of $\mathrm{PI} 3 \mathrm{~K}$ is crucial for the recruitment of specific proteins containing a pleckstrin-homology $(\mathrm{PH})$ domain, FYVE domain, Phox domain, $\mathrm{C1}$ domain, $\mathrm{C} 2$ domain and other lipid-binding domains to the cell membrane (7275).

Protein kinase B/Akt1 is a primary downstream target of PI3K (76). $\mathrm{PKB} / \mathrm{Akt}$ is a 55- $\mathrm{kDa}$ serine threonine protein kinase and a cellular homologue of viral oncoproteins A and C. PKB was first discovered and cloned by research groups in $1991(77,78)$. In mammals, the PKB/Akt subfamily consists of three related genes located in different chromosomes encoding PKB $\alpha / A k t 1$ (14q32), PKB $\beta / A k t 2$ (19q13) and PKB $\gamma / A k t 3$ (1q44). PKB $\beta$ and PKB $\gamma$ share nearly $80 \%$ homology with $\mathrm{PKB} \alpha$, and all the substrates show wide tissue distributions; $\mathrm{PKB} \alpha$ and $\mathrm{PKB} \beta$ show high expression in the brain, heart, thymus, and lungs, and while PKB $\gamma$ shows high expression in the brain and testes, it shows low expression in the heart, lungs, spleen, and skeletal muscles (77-80). All the isoforms differ in phosphorylation pattern and sub-cellular localization. Apparently, the function of Akt depends partly on its sub-cellular localization. Akt1 and Akt2 are located in the cytoplasm and mitochondria, respectively, whereas Akt3 localizes to the nucleus and nuclear membrane (81).

The structure of PKB/Akt consists of three functional domains: an Nterminal $\mathrm{PH}$ domain, a central kinase domain, and a C-terminal domain containing the hydrophobic motif. Two specific sites, one in the kinase domain 
(Threonine 308) and another in the C-terminal regulatory motif (Serine 473), are phosphorylated during full activation of the kinase $(79,82)$. Akt/PKB is recruited to the plasma membrane from the cytoplasm upon different cellular stimuli (76). Plasma membrane recruitment and binding to $\mathrm{PI}(3,4,5) \mathrm{P} 3$ causes conformational changes in Akt, resulting in the exposure of two amino acids, which is essential for its complete activation by phosphoinositide-dependent kinase (PDK) and mammalian target of rapamycin (mTOR)/rictor. One of the sites in a kinase domain, T308, is phosphorylated by PDK1, alleviating the activation loop. Another site in the hydrophobic C-terminal domain, S473, is phosphorylated by PDK2 and is obligatory for full activation (83-86). The activated $\mathrm{PKB} /$ Akt triggers the regulation of downstream signalling molecules, which play significant roles in angiogenesis and cell survival, growth, migration, proliferation and death (87).

Akt-mediated regulation of mTOR involves several mechanisms. mTOR plays a major role in cell growth by regulating protein synthesis through the activation of p70 S6 kinase, which enhances the translational process. Simultaneously, mTOR phosphorylates and inactivates 4E-BP1, which inhibits the translational process (88). mTOR is a component of two multi-protein complexes, mTORC1 and mTORC2 (89). Tuberous sclerosis complex (TSC) 2 binds to the $14-3-3$ proteins upon Akt-mediated phosphorylation. The bound TSC2 complex goes through proteosomal degradation, which activates mTORC1 (90). Apart from this, proline-rich Akt substrate 40 (PRAS40) also plays a role in $\mathrm{mTORC} 1$ regulation. PRAS40 inhibits the interaction of $\mathrm{mTORC} 1$ with its substrates. Akt directly phosphorylates PRAS40, which prevents mTORC1 
cell-growth signalling (91). While our knowledge about mTORC2 is limited, the mTORC2 complex directly phosphorylates the Akt at Ser473 (92).

The cytoprotective function of Akt is considered multifactorial because of the ability of Akt to interact either directly or indirectly for the phosphorylation of different components of cell death pathways. For example, BAD is the proapoptotic molecule of the B-cell lymphoma $(\mathrm{Bcl}) 2$-family and promotes apoptosis by forming a complex with BCL-XL. Akt-mediated phosphorylation of BAD inhibits this interaction with BCL-XL and thus prevents complex formation (93). Similarly, pro-caspase- 9 catalytic activity could be inhibited by Akt-mediated phosphorylation (94). The phosphorylation of FKHRL, a fork-head transcription factor family protein, by Akt leads to nuclear exclusion and inactivation, which further leads to the inhibition of essential components of apoptosis-promoting factors, such as BIM and Fas-ligand. The NF-kB transcription factor complex promotes cell survival in response to several cell death stimuli. Akt phosphorylates and activates $I_{\kappa} B$ kinase, which is an inhibitor of the NF-kB transcription factor. Enhanced degradation of IKB kinase promotes NF-kB nuclear migration, which leads to the activation of cell survival genes (95). Akt also influences the activity of the major tumour suppressor gene p53 through the phosphorylation and activation of murine double minute (MDM)2 protein. MDM2 degrades p53 through the proteosome and E3 ubiquitin ligase activity (96-98).

Akt is also involved in the phosphorylation of different cell proliferation factors, such as cyclin-dependent kinase (CDK) inhibitors p2 $21^{\text {Waf1/Cip1 }}$ and p27 $7^{\text {kip1 }}$ and glycogen synthase kinase-3 (GSK3) (87, 99). The Akt-mediated phosphorylation of cyclin-dependent kinase inhibitors $(\mathrm{CKIs}) \mathrm{p} 21^{\text {Waf1/Cip1 }}$ and 
$\mathrm{p} 27^{\mathrm{kip} 1}$ leads to their shift from nuclear to cytoplasmic localization, thus promoting the transition from the G0 to the S phase (100-102). Akt-mediated inhibition of GSK3 $\beta$ prevents the phosphorylation of $\beta$-catenin, which impedes its degradation, thus enhancing cell proliferation (100). GSK3 $\beta$ inhibition leads to the accumulation of cyclin D1, which facilitates the G1/S progression of the cell cycle (103). While Akt1 predominantly resides in the cytoplasm, under certain physiologic conditions, it briefly enters the nucleus around the S-G2 boundary to participate in cell cycle regulation (104).

\section{Nuclear Akt}

The presence of Akt within the nucleus was first reported in the late 1990s (105). Indeed, some Akt substrates are considered to reside in the nucleus, such as FOXO transcription factor (106). All isotypes of Akt have been shown to transfer into or reside within the nucleus, depending on the type of a wide variety of stimuli, e.g., growth factors, which can initiate the process (107-110). Either Akt kinase does not possess a nuclear localization sequence (NLS) or it has simply remained unknown; yet, but Akt kinase still enters the nucleus. The mechanism behind the nuclear localization of any protein lacking an NLS is not clearly understood. Smaller proteins $(\sim 40 \mathrm{kDa})$ can passively diffuse through the nuclear pores, while larger proteins form a complex with a cytoplasmic cargo protein possessing an NLS (111). Whether Akt has to be phosphorylated and activated for nuclear migration is still under debate. Dominant-negative Akt mutants, which cannot be phosphorylated or activated, have been shown to be localized in the nucleus in HEK293 cells under specific conditions (112). In 
contrast, in PC12 cells after NGF treatment, the same dominant-negative Akt mutant, even if overexpressed, could not be found in the nucleus (113).

In 2002, the first incidence of T-cell leukaemia-1 (TCL1) protein was reported to play a role in Akt nuclear migration (114). TCL1 preferentially binds to the $\mathrm{PH}$ domain of Akt in the plasma membrane and forms a protein complex. Subsequently, within that protein complex, Akt is phosphorylated and migrates into the nucleus (115). TCL1 inhibition or overexpression has been shown to decrease or increase Akt nuclear localization $(116,117)$. Thus, this evidence suggests that TCL1 is a major interaction partner of Akt that plays a vital role in Akt nuclear migration. However, TCL1 protein expression is limited to certain lymphoid cells (118), and Akt nuclear migration has been observed in cells that do not express TCL1 protein (105).

\section{Luminescent conjugated oligothiophenes (LCOs)}

Biomolecule visualization is one of many great tools that have been developed and implemented in cell biology. Initially, silver salt was the first compound found to be useful for staining neuronal tissues, discovered by Golgi in 1873 (119). During the development of visualization tools, visible dyes have been replaced by fluorescent dyes. In principle, staining biomolecules with fluorescent dyes may alter their function, stability and receptor interactions. Therefore, it is important to fully characterize the properties of fluorescent dyes, such as fluorescence emission, stability, and toxicity, prior to implementing them in various experimental applications. Apart from these considerations, the 
labelling chemistry might directly conflict with the nature of the biomolecule under investigation.

Recently, LCOs have been shown to have high fluorescence and photostability, as well as sensitivity and selectivity for certain biomolecules (120). LCOs are a novel class of thiophene probes that were designed to have lengthy conjugated backbones and are hydrophobic in nature. Generally, oligothiophenes are known for their semiconductive properties and their usefulness in photonic and organic electronics (121). Oligothiophenes are nontoxic in nature, which are suitable for staining biomolecules and for imaging experiments (122). The lower numbers of ionic side chains enhance the exposure of the thiophene backbone, which seems to enhance the interactions and change the emission and specificity of the dye (123).

A recent study has shown that the modification of the side chains in oligothiophene compounds could be used for the direct labelling of biomolecules, such as nucleosides and oligonucleosides. 5-(2-Hydroxyethyl)-2,2':5',2"terthiophene was the first fluorescent oligothiophene that was used for the covalent labelling of oligonucleotides $(124,125)$. Apart from the labelling of oligonucleotides, LCOs could be modified to target selective and specific disease-associated protein aggregates or specific cells. It has been published recently, that LCOs could identify the amyloid $\beta$ protein aggregates that are associated with Alzheimer's disease and prion disease (121, 126-128). Two LCOs, p-(pentameric) HTAA (hydrogen thiophene acetic acid) and p-FTAA (formyl thiophene acetic acid), have been shown to pass through the blood brain barrier in vivo successfully and stain these protein aggregates (121). Recently, 
p-FTAA and heptameric (h)-FTAA were shown to specifically stain the misfolded Mallory-Denk Bodies (MDBs). MDBs are the hepatic inclusion bodies that are found in several hepatic disorders, including steatohepatitis and hepatocellular cancer. Other types of hepatic protein inclusions containing p62 and ubiquitin could also be stained by LCOs (129). The Barbarella G. et al were successful in developing oligothiophenes for stem cell visualization, and they have also shown that selective oligothiophenes have the capability to distinguish protein types inside living cells $(120,122,130,131)$. 


\section{Aim}

To elucidate the role of PKB/Akt kinase localization in the maintenance of CSCs and the potential biologic consequences.

More specific aims of the studies were the following:

I. To examine various functionalized LCOs that can be used to specifically stain distinct subpopulations.

II. To identify functionalized LCOs that can specifically bind CSCs from a heterogeneous population.

III. To elucidate the role of nuclear Akt in the maintenance of CSCs.

IV. To investigate the effect of miR301 on potential Akt-mediated biologic consequences. 


\section{Material and methods}

\section{Cells and cell lines}

The first ever-permanent tumour human cell line was established in 1951 from a cervical cancer biopsy of Henrietta Lacks (HeLa) (132). In cancer research, tumour cell line models are important tools for anti-cancer drug development and the study of biological mechanisms as well as deregulated genetic, epigenetic and cell signalling pathways (133). Cell line models have several advantages, such as the ease of handling and manipulating genetic expression vectors, the different types of available cancer cell lines, and the high homogeneity and reproducibility. However, there are also some limitations, including 2D tumour stroma, genomic instability and maintaining tumour genetic diversity (134). In our studies, all the experiments were performed using the following human cancer cell lines: breast cancer - SKBR-3, MDA-MB-468, and MCF-7; prostate cancer - PC-3 and DU-145; cervical cancer - HeLa; colon cancer - HCT 116 and p53 mutant HCT 116; chronic myelogenous leukaemia K562; human embryonic kidney 293; and primary human dermal fibroblasts. The breast cancer SKBR-3 and MDA-MB-468 cell lines were used for mammosphere culture. The culture conditions were described in the respective publications.

\section{Polymerase chain reaction (PCR)}

Polymerase chain reaction ( $P C R)$ is a widely used technique for amplifying a specific gene sequence from an entire DNA sample. This technique was developed in the 1980 s by Kary Mullis, who was rewarded with a Nobel prize 
in 1993 for his excellent work (135). PCR consists of three important phases. The first phase is denaturation, during which double-stranded DNA (dsDNA) melts into single-stranded DNA due to high temperatures of approximately 93$96^{\circ} \mathrm{C}$. The second phase is annealing, in which the temperature is reduced, according to the primers, to anneal the target DNA sequence. The third and final phase is extension, during which the temperature is raised up to $72^{\circ} \mathrm{C}$, which is the optimal temperature for the heat-stable DNA polymerase to start synthesizing complementary DNA strands with the help of supplemented dNTPs (136).

\section{Quantitative PCR (qPCR)}

Quantitative PCR (qPCR) is an advanced type of PCR that allows the detection and measurement of the number of copies produced during each cycle of the PCR process. Two common methods are used to detect PCR products. The first method uses a fluorescent dye, such as SYBR green, which binds to the dsDNA either by intercalation or external binding. Increases in fluorescence intensity represent numbers of the amplified gene of interest, which allows the quantification of the total amount of dsDNA (137). The second detection method uses the 5' to 3' exonuclease activity of Taq DNA polymerase and a nonexpendable probe specially designed to hybridize in close proximity to the forward and/or reverse primers. The probes are labelled with a reporter and a quencher (138). Fluorescent signal from the reporter dye at one terminal end of the probe is inhibited by the quencher at the other terminal end in a normal state, after binding to the target DNA. In the extension phase, the Taq DNA polymerase synthesizes the complementary DNA strand and degrades the probe, releasing 
the reporter dye from the quencher and allowing fluorescence, which can be detected as a measure of amplification. Increase in DNA amplification is directly proportional to fluorescence signal intensity, which allows the quantification of the total amount of PCR product (139). In paper II, iQTM SYBRGreen Supermix was used to determine the relative mRNA expression of each gene. In paper III, TaqMan® Fast Universal PCR Master Mix and TaqMan MicroRNA Assay for miR301 were used for the quantification of miR301expression. The detailed descriptions were described in the respective publications.

\section{Western blot}

Western blot is a semi-quantitative method used in paper II and III for the detection of a specific protein from a protein mixture. The method is based on the separation of proteins with different sizes using sodium dodecyl sulphatepolyacrylamide gel electrophoresis (SDS-PAGE). After separation in the gel, proteins are transferred to a polyvinylidene fluoride (PVDF) membrane. Nonspecific binding sites are blocked using blocking reagents; thereafter, the membranes are incubated with specific primary antibodies of interest, followed by incubation with HRP-conjugated secondary antibodies. The membranes are then washed and developed with Amersham ECL plus. The protein levels are normalized using a housekeeping protein (140). The detailed descriptions of Western blot procedures can be found in the respective publications.

\section{Immunocytochemistry}

Immunocytochemistry (ICC) is a method for visualizing the expression 
and distribution of specific proteins directly or indirectly using protein-specific antibodies conjugated with a fluorophore (141). The most commonly used method is indirect ICC, in which the primary antibody is used against the target protein without conjugation, and the secondary antibody is conjugated with the fluorophore. Then, via confocal microscopy, the fluorophore is excited using lasers of a specific wavelength and emits fluorescence of longer wavelength. In papers II and III, the localization of Akt and PTEN were investigated, respectively, using indirect ICC and breast cancer cell lines. The detailed descriptions of the ICC procedures can be found in the respective publications.

\section{Cell survival assay}

The 3-(4,5-dimethyl-2-thiazolyl) 2,5-diphenyl-2H tetrazolium bromide (MTT) cell survival assay was used in this study. The MTT assay is based on the cleavage of the MTT tetrazolium salt to formazan by reducing molecules, such as mitochondrial NADH, and only viable cells have the ability to convert the MTT tetrazolium salt to formazan (142). In papers I and III, cells were plated $24 \mathrm{~h}$ prior to the experiments in a 96-well plate. Upon appropriate treatment, MTT was added, and the formation of formazan was quantified by measuring absorbance at 570 and $630 \mathrm{~nm}$ using a spectrometer. The detailed description of the MTT assay can be found in the respective publications.

\section{Soft agar assay}

The soft agar assay is a gold standard assay for determining cellular transformation, tumourigenicity and self-renewal properties. The soft agar assay 
is based on the principle of anchorage dependency. CSCs grow in an anchorage-independent manner to form colonies, which determines the cellular transformation, tumourigenicity and self-renewal properties. (143). 3D growth conditions of cancer stem-like cells more accurately reflect the environment of growing tumours. In paper II, a soft agar assay was performed in a 6-well plate; each well contained 2 layers of agarose (Calbiochem, Darmstadt, Germany) and was supplemented with maintenance medium. Single-cell suspensions were added into the upper layer of agarose. The cells were incubated for 2-3 weeks and were fed twice a week with fresh maintenance medium. After formation, colonies were observed, stained with $0.005 \%$ crystal violet (Acros Organics), and counted using ImageJ software.

\section{Flow cytometry}

Flow cytometry is also based on fluorescence detection and has continued to develop over the years since the 1960s (144). Single-cell suspensions are stained and passed through a laser that detects the fluorescence intensity of each cell. In paper I, flow cytometry was used to obtain information about oligothiophenes in a large number of cells. In paper II, an Aldefluor assay kit was used to analyse ALDH enzymatic activity in breast cancer cells. Furthermore, the prevalence of CD24-PE and CD44-APC surface markers was also determined in the breast cancer cells. In papers II and III, cell cycle analysis was performed by DNA content quantification using propidium iodide DNA staining. In papers II and III, cell death was analysed using the Po-Pro and 7-aminoactinomycin D (7-AAD) dyes, respectively. In papers I-III, the 
fluorescence intensities of the samples were quantified using a Gallios flow cytometer (Beckman Coulter, Inc.,), and the data were analysed using Kaluza software (Beckman Coulter, Inc.). The detailed description of the flow cytometry staining procedures can be found in the respective publications.

\section{Cell migration assay}

A cell migration assay was used to analyse migration capacity after scratching. The degree of cell ingrowth into the scratch indicated cell migration capacity (145). In paper III, after co-transfection of miR301 inhibitor and mimic with Akt, cell layers cultured in 6-well plates were scratched. Serial bright-field images were captured at different time points using a JuLi Smart Fluorescence cell imager. Scratch areas were quantified using ImageJ software.

\section{Bioinformatics and statistics}

All the statistical analyses (one-way and two-way ANOVA, including Bonferroni post hoc tests) were performed using Graph Pad Prism (version 5.0 d), and a $p$-value $<0.05$ wasconsidered statistically significant. Unless mentioned, all presented data represent the averages of a minimum of 3 independent experiments. Target genes for miR301 were predicted by the following computeraided algorithms: TargetScan (http://www.targetscan.org) and PicTar (http://pictar.mdc-berlin.de). 


\section{Results and Discussion}

\section{Paper 1: Cell type-related differences in staining with pentameric thiophene derivatives}

The aim of the study was to identify new, functionalized LCOs that can be used to selectively stain distinct subpopulations and to identify functionalized LCOs that can specifically bind CSCs within a heterogeneous population of cancer cells. We tested different LCOs as markers for cancer cell stemness in collaboration with Prof. P. Nilsson's group. A library of functional LCOs was used for the selective detection of specific cells or disease-associated protein aggregates. As shown in previous papers, LCOs can effectively stain proteins related to various diseases, such as Alzheimer's disease and prion disease (121, 127, 128). Here, we show differential staining patterns of LCOs in various cells, including cancer cells. LCOs with different imidazole motifs, along with the thiophene backbone, have shown interesting staining patterns in cancer cells, in particular. For instance, the LCO p-HTMI differentially stained cells depending on p53 expression pattern. On the other hand, the LCO p-HTAA has been shown to stain a rare population of cells in SKBR3, MDAMB468 and MCF7 breast cancer cell lines. Thus, LCOs that are capable of staining rare populations of cells might serve as excellent tools for specifically staining CSCs. This finding would remarkably impact further investigations in the field of stem cell biology. However, further experiments are required to clarify these findings. 


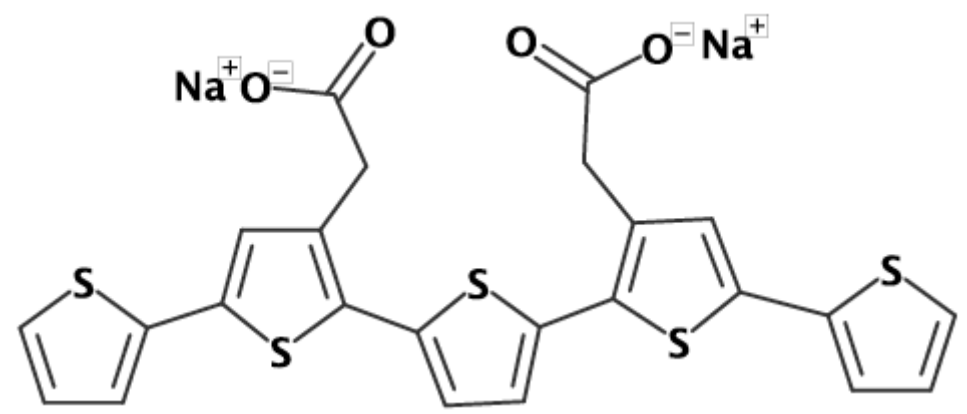

Figure 1. Chemical structure of the pentameric thiophene probe, p-HTAA 


\section{Paper 2: Nuclear-localized Akt enhances breast cancer stem-like cells through the counter regulation of $\mathrm{p} 21^{\text {Waf1/Cip1 }}$ and $\mathrm{p} 27^{\mathrm{kip} 1}$}

The aim of this study was to investigate the intracellular localization of Akt and its effect on the maintenance of cancer stem-like cell (CSC) populations. We observed that nuclear Akt in transiently transfected breast cancer cell lines (SKBR3 and MDAMB468) enhances the CSC population detected as highly positive for $\operatorname{ALDH}\left(\mathrm{ALDH}^{+/ / \text {igh }}\right)$. These $\mathrm{ALDH}^{+/ / \text {igh }}$ cells show a typical CD44//ligh $/ C D 24^{- \text {Low }}$ phenotype of breast cancer stem cells. A similar phenomenon was observed when the transiently transfected breast cancer cells were cultured under non-adherent conditions. The non-adherent conditions favour mammosphere formation and have been widely used for the enhancement of CSCs. The results described above confirm that the PI3K/Akt pathway is important for the maintenance of stemness, and they are consistent with previous studies, in which the PI3K/Akt pathway has been shown to serve a vital function in mouse and cynomolgus monkey embryonic stem cells (146, 147). The nuclear Akt-mediated enhancement of CSCs was completely reversed after treatment with the Akt-specific inhibitor, triciribine in both adherent and nonadherent transfected breast cancer cells. Recently, a similar decrease in CSCs was shown after triciribine treatment in T-cell acute lymphoblastic leukaemia (TALL) (148). 


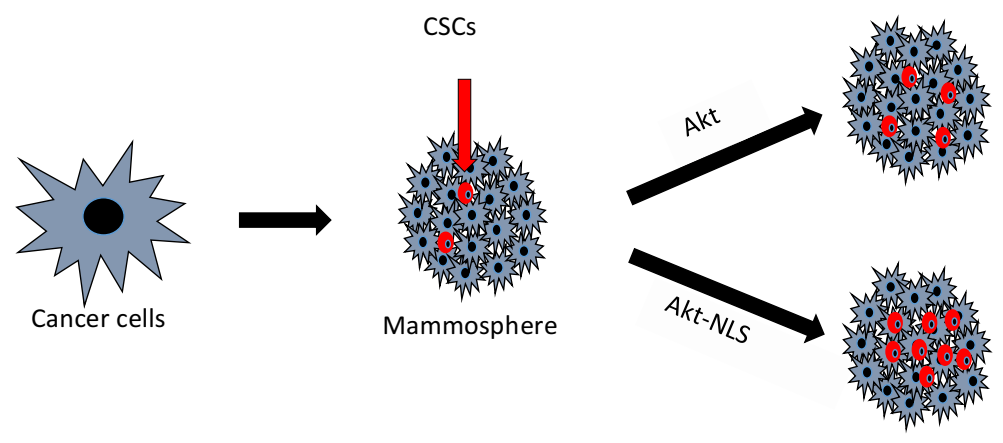

Figure 2. Graphical representation of enhancement of CSCs by Akt and nuclear Akt

Further, to explore the role of nuclear Akt in the mechanism of CSC enhancement, we used immunoblotting techniques to investigate the expression of well-known pluripotent stem cell factors, known as Yamanaka factors, Oct4, Sox2, KLF4 and cMyc, in breast cancer cells. Akt has been shown to enhance stemness through regulating and/or stabilizing reprogramming factors (149-151). In this study, increased protein expression of Oct3/4, cMyc, Nanog and Sox2 were observed in both Akt wild-type (WT) and Akt-NLS construct cells compared with that of the control cells; however, differences between Akt WT and Akt-NLS construct cells were observed at the mRNA level. Akt WT cells exhibit enhanced mRNA levels of Oct4, cMyc, Nanog and Sox2, while Akt-NLS cells show significant upregulation of only cMyc. To understand the functional aspects of the differential expression of these stemness markers, we performed a 3D-soft agar colony formation assay showing that Akt-NLS transfected cells have a significantly higher colony-forming capability.

For a closer look into the nuclear Akt role in cell proliferation, the cell cycle profile of the Akt-transfected breast cancer cells was studied. Previously, several 
studies have shown that nuclear Akt reduces the G0/G1 phase by the phosphorylation of the cell cycle inhibitory proteins p2 $1^{\text {Waf1/Cip1 }}$ and p2 $7^{\text {kip1 }}(101$, 102), which promotes the cell cycle regulators cyclin D1 and CDK2 $(99,116)$. Based on these observations, we investigated two CKIs (p21 Waf1/Cip1 and p27 ${ }^{\mathrm{kip} 1}$ ) and cyclins in both Akt WT and Akt-NLS-transfected cells using immunoblotting techniques. The transcriptional and translational regulation of CKIs and cyclins has been shown to differ in Akt and Akt-NLS cells. Therefore, cell cycle progression was studied by staining DNA content with propidium iodide. Indeed, the Akt-NLS transfected cells showed shorter G0/G1 phase, and a corresponding enhancement in the percentage of cells in the G2 phase. Thus, the Akt- and Akt-NLS-mediated stabilization of cyclin proteins was found to be similar to that of reprogramming factors, along with the inhibition of $\mathrm{p} 21^{\text {Waf1/Cip } 1}$, as both correspond to an increase in the number of CSC-like cells.

Our study found that nuclear Akt is important for the maintenance and proliferation of CSCs. Specifically targeting nuclear Akt could lead to more selective or improved treatments against CSCs. Intriguingly, available Aktspecific inhibitors lack the distinguishing (cytoplasmic or nuclear Akt and Akt subtypes) characteristics that result in major side effects (152). 


\section{Paper 3: Inhibition of miR301 enhances Akt-mediated cell proliferation by accumulation of PTEN in the nucleus and affects cell-cycle regulatory proteins}

In paper III, the aim was to investigate the effect of micro-RNA 301 (miR301) on Akt-mediated biological functions in breast cancer cells. Concurrent with our previous publication on Akt cellular compartmentalization enhancing CSCs, we proposed that more selective and specific novel targets of Akt could be obtained by evaluating the role of miRs. Several studies have suggested that miR expression patterns are robustly related to specific characteristics of cancer cells (153-155). Therefore, we evaluated this possibility by examining the miR profiles in MCF7, SKBR3 and HEK293 cells transiently transfected with Akt. When Akt was overexpressed, a marked decrease in miR301 expression was found in MCF7 and HEK293 cells; furthermore, the expression levels of Akt and miR301 were confirmed using Western blot and qPCR.

To explore the mechanism behind the downregulation of miR301 upon Akt overexpression, we evaluated the biological role of miR301. A miR301specific inhibitor and a mimic were utilized to inhibit and increase miR301 expression in breast cancer cells. Several studies have shown that Akt-driven enhancement of cell survival pathways plays an important role in drug resistance (156-158). Therefore, we investigated metabolic/mitochondrial activity and cell migration after miR301 inhibition in the presence of Akt. Intriguingly, we found a significant increase in cell survival and cell migration upon miR301 downregulation mediated by the miR301 inhibitor and Akt compared with the controls. 
As we have shown in paper II (159), Akt plays a major role in the cell cycle profile. Nuclear Akt accumulation causes a short G1 phase via the phosphorylation of $\mathrm{p} 21^{\text {Waf1/Cip1 }}$ and $\mathrm{p} 27^{\mathrm{kip} 1}$, which leads to reduced cell cycle inhibition by p2 $1^{\text {Waf1/Cip1 }}$ and p $27^{\mathrm{kip}}(160)$. In this study, we observed similar effects upon the downregulation of miR301 mediated by the miR301 inhibitor and Akt. In addition, to confirm the cell survival functions in our model, we analysed the cell death pattern of these cells. We found that cells overexpressing the miR301 inhibitor with Akt showed lower staining for Po-Pro (apoptotic dye) and 7-AAD (necrotic dye).

Further studies were performed to understand the molecular mechanism behind the miR301 inhibition-mediated enhancement of Akt biological functions. A recent study has shown that there is a strong correlation between miR301 and PTEN levels in human breast cancer patients (55). We investigated miR301 targets (i.e., PTEN, PI3K and FoxF2) using immunoblotting techniques. We observed an enhanced protein expression of PTEN, PI3K and FoxF2 upon the down-regulation of miR301 mediated by the miR301 inhibitor and Akt compared with the controls. Intriguingly, PI3K is a known Akt activator (69), and PTEN is a known inhibitor of the Akt pathway (161). To understand these contrasting results, we evaluated the marked upregulation of phosphorylated PI3K levels, which has not been observed in the case of PTEN. In several cancer cell types, large quantities of PTEN localize to the nucleus (162). We also observed a similar trend in our model, with the nuclear localization of PTEN occurring upon the extreme downregulation of miR301 mediated by the miR301 inhibitor and Akt. Our results were also found to be consistent with previous findings showing 
nuclear PTEN to be unable to inhibit the Akt pathway (68). These observations are further supported by enhanced total and phosphorylated protein levels of Akt and its downstream targets (mTOR and P70S) upon the downregulation of miR301 mediated by the miR301 inhibitor and Akt compared with the controls. In conclusion, these data provide a foundation for the development of miR301based inhibitors targeting the Akt pathway. 


\section{General Discussion}

Despite the development of new agents targeting a broad range of cancer cells, the genetic status and unknown cause of possible gene alterations among cancer cells that lead to recurrence remain huge clinical challenges. For the development of targeted therapies of specific oncogenic pathways, as well as to improve clinical therapeutic efficacy and reduce side effects, a comprehensive characterization and analysis of genetic alterations in cancer cells is required (163). Mutational analyses have shown that deregulation of the PI3K-Akt-mTOR signalling pathway contributes to tumour progression, angiogenesis, stemness maintenance, cell proliferation, survival and migration in various cancer cell types $(146,147,164)$. The role of the PI3K-Akt-mTOR signalling pathway in cancer recurrence and its biological consequences cannot be predicted by relying on a single factor. Therefore, in this study, we focused on both CSCs and miRs because the presence of CSCs and the deregulation of miRs are now widely accepted and have been reported in the majority of cancer types $(34,165)$.

Therefore, in paper I, we examined a whole panel of LCOs towards different cell types (especially cancer cells) with the objective of identifying various functionalized LCOs that could be used to stain specifically CSCs. From the screened library of LCOs, we found p-HTMI and p-HTAA, which have shown the potential to stain a specific cell subpopulation among breast cancer cells.

In paper II, we continued to study CSCs and the related mechanisms by analysing the intracellular compartmentalization of Akt. Akt localization gained substantial attention in the last decades its function depends on its localization. Cytoplasmic Akt is well known for its cell survival effects, while mitochondrial Akt 
localization regulates the $\beta$ subunit of ATP synthase and inhibits GSK- $3 \beta$ function (166).The role of nuclear Akt is not clearly understood, and it may support cell proliferation or cell death, depending upon the stimulus and cell cycle stage $(99$, 167). To understand the impact of nuclear Akt on cell proliferation, the connection between Akt localization and stemness maintenance in human breast cancer cells has been deduced. Moreover, Akt and its nuclear compartmentalization have been shown to impact the enhancement of CSCs. To confirm that Akt mediates CSC enhancement, inhibition studies using triciribine, an inhibitor of Akt activation and phosphorylation were performed. Triciribine has been shown to significantly inhibit the CSCs in T-ALL (148). This indicates that Akt activation/phosphorylation and nuclear localization are directly correlated to the number of CSCs. Additionally, Akt and its nuclear compartmentalization result in different transcriptional regulation of pluripotent factors, cyclins and CKIs. We explored the functional translation of stemness properties by performing a 3D colony-forming assay and observed that nuclear Akt can increase the number of colonies compared with that of the control. Furthermore, we examined mTOR expression, a downstream regulator of the PI3K/Akt pathway and a key player in autophagy $(168,169)$. Our results show a significant increase in mTOR activity and Akt activation in both Akt- and nuclear Aktoverexpressing cells. Thus, this study strongly supports that the PI3K/Akt/mTOR pathway plays a critical role in CSC proliferation.

Paper III was designed to study the role of miRs in the regulation of the $\mathrm{PI3K} / \mathrm{Akt} / \mathrm{mTOR}$ pathway. We overexpressed Akt for miR profiling in MCF7, SKBR3 and HEK293 cells, and we found that miR301 expression was 
subsequently downregulated. We observed that the downregulation of miR301expression was strongly associated with enhanced Akt-mediated cell survival, proliferation and migration. Therefore, as described above, $\mathrm{PI} 3 \mathrm{~K} / \mathrm{Akt} / \mathrm{mTOR}$ pathway deregulation plays a crucial role in cancer.

Shi W.et al., have recently shown that there is a direct correlation between miR301 and PTEN (a negative regulator of the PI3K/Akt/mTOR pathway) expression in human breast cancer patients (55). Therefore, we hypothesized that miR301 downregulation inhibits PTEN protein expression. However, we found that miR301 downregulation enhances PTEN protein levels. Enhanced PTEN was mostly localized in the nucleus. In numerous cancer cell types, PTEN localizes to the nucleus (162), and it was recently reported that nuclear PTEN does not affect the PI3K/Akt/mTOR pathway (68). Furthermore, the above results might be applied to a subpopulation of cells isolated from cancer cells. Targeting nuclear Akt and miR301-based inhibitors opens up new avenues for the selective or preferential targeting of CSCs and the Akt pathway in cancer therapy. 


\section{Conclusions}

- After screening the LCO library, we found well-defined probes with the ability to stain different cell types.

- The most interesting probes were $\mathrm{p}-\mathrm{HTMI}$ and $\mathrm{p}-\mathrm{HTAA}$ because they specifically stain rare populations of cells in breast cancer cell lines.

- Intracellular Akt localization was found to play a vital role in the maintenance of stemness by regulating cell proliferation and cell cycle progression.

- The downregulation of miR301 was shown to be directly correlated to the Akt-PI3K pathway in breast cancer cells through the accumulation of PTEN in the nucleus. 


\section{Future perspectives}

Across the globe, many scientists and researchers pursue the development of prognostic biomarkers to improve cancer treatments. Many molecules have been identified to estimate treatment efficacy and patient prognosis by several approaches, but these seem to be only partially effective. In our approach, we targeted the PKB/Akt1 pathway and its relevance in cancer development to develop a platform for the generation of new targets for cancer therapies. However, many questions remain to be answered, some of which include the following:

- Although we have found that the LCOs such as p-HTMI and p-HTAA have the potential to stain subpopulations that are most likely CSCs, it would be interesting to further confirm this by co-staining with other consistent CSC markers, i.e., ALDH +//igh, $\mathrm{CD} 44^{+/ / \text {High }}$, and CD24 $4^{- \text {Llow }}$.

- It will be very interesting to understand the mechanism behind the intracellular localization of Akt. As Akt does not possess a classical NLS, the intracellular localization of this molecule must either be mediated by another molecule that has an NLS or it might possess an unknown, unique sequence that facilitates nuclear transfer.

- We observed miR301 inhibitory regulation of the Akt pathway by the accumulation of PTEN in the nucleus. Therefore, it would be very interesting to investigate the effect of miR301 on Akt localization in breast cancer cells. 


\section{Acknowledgements}

First of all, I would like to thank Prof. Marek J. Łos for having faith in me and for this wonderful opportunity to do a PhD so that I could utilize this platform to learn a lot and be able to think optimistic about a career in research.

I would like to thank Prof. Karin Roberg for being my supervisor at the critical stage of my $\mathrm{PhD}$ and for being friendly and supportive in providing guidance towards finishing it effectively.

I take this opportunity to thank my co-supervisors, Dr. Piotr Religa and Dr. Mehrdad Rafat for their guidance, encouragement and kind support during my study period.

I am very thankful to Prof. Peter Påhlsson and Prof. May Griffith for all the useful discussions, advices and sharing of thoughts and information about current aspects of science over lunch and coffee.

I would like to extend my gratitude to Prof.Maria Jenmalm who has trained and taught me the critical aspects of approaching and performing science at the initial stages of my research career.

I would like to express my sincere thanks to my previous colleagues and friends, Artur and Jagan for their timely help, guidance and valuable suggestions then and there during my PhD.

I am thankful to all the people from cell biology, floor 10 whom I have met since 2010, Anna-Kristina, Eva, Patrik, Mårten, Queenie, Administration (Camilla and Anna), Autoclave personnel (Lena and Anna) and all the past and present fellow lab/floor members, who have been extremely friendly and helpful with their fun conversations in the coffee room and short lessons about Swedish language and culture.

I am extremely thankful to my friends, Amit, Jaywant (and family), Sumit and Hirak who has taken the job of mentoring me voluntarily, been with me in my ups and downs, lent their hands without hesitation for personal/professional helps and treated me as family. 
I am very grateful and fortunate to have Liv, Mother Sally and Father Sven-Olov as my friends who have inspired me by their amazing nature and strong bond of friendship.

Furthermore, I am so blessed to have great bunch of friends around me all the time. I would like to thank Sandeep, Miraz, Elmira, Rebecca, Sudeep, Vidya, Jaya, Ravi, Shanta, Daniel, Hardik, Meenu and Jacob for being with me. Life in Sweden without them is unimaginable. In addition, I would like to mention my thanks to friends abroad who are interested in my well-being, Anu, Viji, Sahana, Shrestha, Devanita, Franklin, S. Bhandari, Rakibul and Madhu. And I take this wonderful opportunity to thank all the great minds and hearts who have inspired me all the way, all these years till date here in Sweden.

Last but not least, I am delighted to convey my heartfelt gratitude to my beloved mother, father, brothers and everyone in my family, who has been by my side with encouraging words, when I started the journey to explore my career outside my motherland. Without them, I am not who I am today! 


\section{References}

1. Sudhakar A. History of Cancer, Ancient and Modern Treatment Methods. Journal of cancer science \& therapy. 2009;1(2):1-4.

2. WHO. International Agency of Cancer research, GLOBOCAN 2012 [Available from: http://globocan.iarc.fr/Pages/fact_sheets_cancer.aspx (last accessed 24th February 2014).

3. Aktipis CA, Boddy AM, Gatenby RA, Brown JS, Maley CC. Life history trade-offs in cancer evolution. Nature reviews Cancer. 2013;13(12):883-92.

4. Rose MR, Mueller LD. Stearns, Stephen C., 1992. The Evolution of Life Histories. Oxford University Press, London xii +249 pp., £16.95. Journal of Evolutionary Biology. 1993;6(2):304-6.

5. Ferlay J, Soerjomataram I, Dikshit R, Eser S, Mathers C, Rebelo M, et al. Cancer incidence and mortality worldwide: sources, methods and major patterns in GLOBOCAN 2012. International journal of cancer Journal international du cancer. 2015;136(5):E359-86.

6. de Martel C, Ferlay J, Franceschi S, Vignat J, Bray F, Forman D, et al. Global burden of cancers attributable to infections in 2008: a review and synthetic analysis. The Lancet Oncology. 2012;13(6):607-15.

7. Uno K, lijima K, Shimosegawa T. Gastric cancer development after the successful eradication of Helicobacter pylori. World journal of gastrointestinal oncology. 2016;8(3):271-81.

8. Herceg Z, Hainaut P. Genetic and epigenetic alterations as biomarkers for cancer detection, diagnosis and prognosis. Molecular oncology. 2007;1(1):26-41.

9. Bielas JH, Loeb KR, Rubin BP, True LD, Loeb LA. Human cancers express a mutator phenotype. Proceedings of the National Academy of Sciences of the United States of America. 2006;103(48):18238-42.

10. Fishel R, Wilson T. MutS homologs in mammalian cells. Current opinion in genetics \& development. 1997;7(1):105-13.

11. Stratton MR, Campbell PJ, Futreal PA. The cancer genome. Nature. 2009;458(7239):719-24.

12. Hanahan D, Weinberg RA. The hallmarks of cancer. Cell. 2000;100(1):57-

70.

13. Hanahan D, Weinberg RA. Hallmarks of cancer: the next generation. Cell. 2011;144(5):646-74.

14. Kelland L. The resurgence of platinum-based cancer chemotherapy. Nature reviews Cancer. 2007;7(8):573-84.

15. Kline CL, El-Deiry WS. Personalizing colon cancer therapeutics: targeting old and new mechanisms of action. Pharmaceuticals. 2013;6(8):988-1038.

16. Xu G, McLeod HL. Strategies for enzyme/prodrug cancer therapy. Clinical cancer research : an official journal of the American Association for Cancer Research. 2001;7(11):3314-24.

17. Gerber DE. Targeted therapies: a new generation of cancer treatments. American family physician. 2008;77(3):311-9.

18. Waldner MJ, Neurath MF. The molecular therapy of colorectal cancer. Molecular aspects of medicine. 2010;31(2):171-8. 
19. O'Brien SG, Guilhot F, Larson RA, Gathmann I, Baccarani M, Cervantes $F$, et al. Imatinib compared with interferon and low-dose cytarabine for newly diagnosed chronic-phase chronic myeloid leukemia. The New England journal of medicine. 2003;348(11):994-1004.

20. Rivera S, Villa J, Quero L, Hennequin C. Adjuvant radiotherapy for rectal cancer: recent results, new questions. Clin Res Hepatol Gastroenterol. $2011 ; 35(1): 17-22$.

21. Lomax ME, Folkes LK, O'Neill P. Biological consequences of radiationinduced DNA damage: relevance to radiotherapy. Clinical oncology. 2013;25(10):578-85.

22. Reya T, Morrison SJ, Clarke MF, Weissman IL. Stem cells, cancer, and cancer stem cells. Nature. 2001;414(6859):105-11.

23. Polyak K, Hahn WC. Roots and stems: stem cells in cancer. Nature medicine. 2006;12(3):296-300.

24. Roesch A, Fukunaga-Kalabis M, Schmidt EC, Zabierowski SE, Brafford PA, Vultur A, et al. A temporarily distinct subpopulation of slow-cycling melanoma cells is required for continuous tumor growth. Cell. 2010;141(4):58394.

25. Al-Hajj M, Wicha MS, Benito-Hernandez A, Morrison SJ, Clarke MF. Prospective identification of tumorigenic breast cancer cells. Proceedings of the National Academy of Sciences of the United States of America. 2003;100(7):3983-8.

26. Chen J, Li Y, Yu TS, McKay RM, Burns DK, Kernie SG, et al. A restricted cell population propagates glioblastoma growth after chemotherapy. Nature. 2012;488(7412):522-6.

27. Driessens G, Beck B, Caauwe A, Simons BD, Blanpain C. Defining the mode of tumour growth by clonal analysis. Nature. 2012;488(7412):527-30.

28. Schepers AG, Snippert HJ, Stange DE, van den Born M, van Es JH, van de Wetering $M$, et al. Lineage tracing reveals Lgr5+ stem cell activity in mouse intestinal adenomas. Science. 2012;337(6095):730-5.

29. Singh SK, Hawkins C, Clarke ID, Squire JA, Bayani J, Hide T, et al. Identification of human brain tumour initiating cells. Nature. 2004;432(7015):396401.

30. O'Brien CA, Pollett A, Gallinger S, Dick JE. A human colon cancer cell capable of initiating tumour growth in immunodeficient mice. Nature. 2007;445(7123):106-10.

31. Li C, Heidt DG, Dalerba P, Burant CF, Zhang L, Adsay V, et al. Identification of pancreatic cancer stem cells. Cancer research. 2007;67(3):1030-7.

32. Prince ME, Sivanandan R, Kaczorowski A, Wolf GT, Kaplan MJ, Dalerba $\mathrm{P}$, et al. Identification of a subpopulation of cells with cancer stem cell properties in head and neck squamous cell carcinoma. Proceedings of the National Academy of Sciences of the United States of America. 2007;104(3):973-8.

33. Collins AT, Berry PA, Hyde C, Stower MJ, Maitland NJ. Prospective identification of tumorigenic prostate cancer stem cells. Cancer research. 2005;65(23):10946-51.

34. Lage $\mathrm{H}$. An overview of cancer multidrug resistance: a still unsolved problem. Cellular and molecular life sciences : CMLS. 2008;65(20):3145-67. 
35. Gottesman MM, Fojo T, Bates SE. Multidrug resistance in cancer: role of ATP-dependent transporters. Nature reviews Cancer. 2002;2(1):48-58.

36. Bao S, Wu Q, McLendon RE, Hao Y, Shi Q, Hjelmeland AB, et al. Glioma stem cells promote radioresistance by preferential activation of the DNA damage response. Nature. 2006;444(7120):756-60.

37. Diehn M, Cho RW, Lobo NA, Kalisky T, Dorie MJ, Kulp AN, et al. Association of reactive oxygen species levels and radioresistance in cancer stem cells. Nature. 2009;458(7239):780-3.

38. Cheng T. Cell cycle inhibitors in normal and tumor stem cells. Oncogene. 2004;23(43):7256-66.

39. Zhang M, Rosen JM. Stem cells in the etiology and treatment of cancer. Current opinion in genetics \& development. 2006;16(1):60-4.

40. Ginestier C, Hur MH, Charafe-Jauffret E, Monville F, Dutcher J, Brown M, et al. ALDH1 is a marker of normal and malignant human mammary stem cells and a predictor of poor clinical outcome. Cell stem cell. 2007;1(5):555-67.

41. Karamboulas C, Ailles L. Developmental signaling pathways in cancer stem cells of solid tumors. Biochimica et biophysica acta. 2013;1830(2):2481-95. 42. Hayes J, Peruzzi PP, Lawler S. MicroRNAs in cancer: biomarkers, functions and therapy. Trends in molecular medicine. 2014;20(8):460-9.

43. Lee RC, Feinbaum RL, Ambros V. The C. elegans heterochronic gene lin4 encodes small RNAs with antisense complementarity to lin-14. Cell. 1993;75(5):843-54.

44. Jansson MD, Lund AH. MicroRNA and cancer. Molecular oncology. 2012;6(6):590-610.

45. Krol J, Loedige I, Filipowicz W. The widespread regulation of microRNA biogenesis, function and decay. Nature reviews Genetics. 2010;11(9):597-610.

46. Mattiske S, Suetani RJ, Neilsen PM, Callen DF. The oncogenic role of miR-155 in breast cancer. Cancer epidemiology, biomarkers \& prevention : a publication of the American Association for Cancer Research, cosponsored by the American Society of Preventive Oncology. 2012;21(8):1236-43.

47. Song B, Wang C, Liu J, Wang X, Lv L, Wei L, et al. MicroRNA-21 regulates breast cancer invasion partly by targeting tissue inhibitor of metalloproteinase 3 expression. Journal of experimental \& clinical cancer research : CR. 2010;29:29. 48. $\mathrm{Xu} \mathrm{XH}$, Li DW, Feng H, Chen HM, Song YQ. MiR-300 regulate the malignancy of breast cancer by targeting p53. International journal of clinical and experimental medicine. 2015;8(5):6957-66.

49. Kong X, Li G, Yuan Y, He Y, Wu X, Zhang W, et al. MicroRNA-7 inhibits epithelial-to-mesenchymal transition and metastasis of breast cancer cells via targeting FAK expression. PloS one. 2012;7(8):e41523.

50. Rivas MA, Venturutti L, Huang YW, Schillaci R, Huang TH, Elizalde PV. Downregulation of the tumor-suppressor miR-16 via progestin-mediated oncogenic signaling contributes to breast cancer development. Breast cancer research : BCR. 2012;14(3):R77.

51. Cheng CW, Wang HW, Chang CW, Chu HW, Chen CY, Yu JC, et al. MicroRNA-30a inhibits cell migration and invasion by downregulating vimentin expression and is a potential prognostic marker in breast cancer. Breast cancer research and treatment. 2012;134(3):1081-93. 
52. Lee EJ, Gusev Y, Jiang J, Nuovo GJ, Lerner MR, Frankel WL, et al. Expression profiling identifies microRNA signature in pancreatic cancer. International journal of cancer Journal international du cancer. 2007;120(5):1046-54.

53. Jiang J, Gusev Y, Aderca I, Mettler TA, Nagorney DM, Brackett DJ, et al. Association of MicroRNA expression in hepatocellular carcinomas with hepatitis infection, cirrhosis, and patient survival. Clinical cancer research : an official journal of the American Association for Cancer Research. 2008;14(2):419-27.

54. Ma X, Yan F, Deng Q, Li F, Lu Z, Liu M, et al. Modulation of tumorigenesis by the pro-inflammatory microRNA miR-301a in mouse models of lung cancer and colorectal cancer. Cell Discovery. 2015;1:15005.

55. Shi W, Gerster K, Alajez NM, Tsang J, Waldron L, Pintilie M, et al. MicroRNA-301 mediates proliferation and invasion in human breast cancer. Cancer research. 2011;71(8):2926-37.

56. Gonsalves CS, Li C, Malik P, Tahara SM, Kalra VK. Peroxisome Proliferator alpha mediated transcription of miR-301a and miR-454 and their host gene SKA2 regulate Endothelin-1 and PAI-1 expression in sickle cell disease. Bioscience reports. 2015.

57. Inui M, Martello G, Piccolo S. MicroRNA control of signal transduction. Nature reviews Molecular cell biology. 2010;11(4):252-63.

58. Lu J, Getz G, Miska EA, Alvarez-Saavedra E, Lamb J, Peck D, et al. MicroRNA expression profiles classify human cancers. Nature. 2005;435(7043):834-8.

59. Rosenfeld N, Aharonov R, Meiri E, Rosenwald S, Spector Y, Zepeniuk M, et al. MicroRNAs accurately identify cancer tissue origin. Nature biotechnology. 2008;26(4):462-9.

60. Bouchie A. First microRNA mimic enters clinic. Nature biotechnology. 2013;31(7):577.

61. Janssen HL, Reesink HW, Lawitz EJ, Zeuzem S, Rodriguez-Torres M, Patel K, et al. Treatment of HCV infection by targeting microRNA. The New England journal of medicine. 2013;368(18):1685-94.

62. Gebert LF, Rebhan MA, Crivelli SE, Denzler R, Stoffel M, Hall J. Miravirsen (SPC3649) can inhibit the biogenesis of miR-122. Nucleic acids research. 2014;42(1):609-21.

63. Whitman M, Kaplan DR, Schaffhausen B, Cantley L, Roberts TM. Association of phosphatidylinositol kinase activity with polyoma middle-T competent for transformation. Nature. 1985;315(6016):239-42.

64. Hennessy BT, Smith DL, Ram PT, Lu Y, Mills GB. Exploiting the PI3K/AKT pathway for cancer drug discovery. Nature reviews Drug discovery. 2005;4(12):988-1004.

65. Zhou BP, Hu MC, Miller SA, Yu Z, Xia W, Lin SY, et al. HER-2/neu blocks tumor necrosis factor-induced apoptosis via the Akt/NF-kappaB pathway. The Journal of biological chemistry. 2000;275(11):8027-31.

66. Nassif NT, Lobo GP, Wu X, Henderson CJ, Morrison CD, Eng C, et al. PTEN mutations are common in sporadic microsatellite stable colorectal cancer. Oncogene. 2004;23(2):617-28.

67. Baker SJ. PTEN enters the nuclear age. Cell. 2007;128(1):25-8. 
68. Lindsay Y, McCoull D, Davidson L, Leslie NR, Fairservice A, Gray A, et al. Localization of agonist-sensitive Ptdlns $(3,4,5) \mathrm{P} 3$ reveals a nuclear pool that is insensitive to PTEN expression. Journal of cell science. 2006;119(Pt 24):51608.

69. Vivanco I, Sawyers CL. The phosphatidylinositol 3-Kinase AKT pathway in human cancer. Nature reviews Cancer. 2002;2(7):489-501.

70. Katso R, Okkenhaug K, Ahmadi K, White S, Timms J, Waterfield MD. Cellular function of phosphoinositide 3-kinases: implications for development, homeostasis, and cancer. Annual review of cell and developmental biology. 2001;17:615-75.

71. Vanhaesebroeck B, Waterfield MD. Signaling by distinct classes of phosphoinositide 3-kinases. Experimental cell research. 1999;253(1):239-54.

72. Fruman DA, Meyers RE, Cantley LC. Phosphoinositide kinases. Annual review of biochemistry. 1998;67:481-507.

73. Pawson $T$, Nash $P$. Protein-protein interactions define specificity in signal transduction. Genes \& development. 2000;14(9):1027-47.

74. Hiles ID, Otsu M, Volinia S, Fry MJ, Gout I, Dhand R, et al. Phosphatidylinositol 3-kinase: structure and expression of the $110 \mathrm{kd}$ catalytic subunit. Cell. 1992;70(3):419-29.

75. Jimenez C, Jones DR, Rodriguez-Viciana P, Gonzalez-Garcia A, Leonardo $\mathrm{E}$, Wennstrom $\mathrm{S}$, et al. Identification and characterization of a new oncogene derived from the regulatory subunit of phosphoinositide 3-kinase. The EMBO journal. 1998;17(3):743-53.

76. Ye K. PIKE/nuclear PI 3-kinase signaling in preventing programmed cell death. Journal of cellular biochemistry. 2005;96(3):463-72.

77. Coffer PJ, Woodgett JR. Molecular cloning and characterisation of a novel putative protein-serine kinase related to the cAMP-dependent and protein kinase C families. European journal of biochemistry / FEBS. 1991;201(2):475-81.

78. Jones PF, Jakubowicz T, Pitossi FJ, Maurer F, Hemmings BA. Molecular cloning and identification of a serine/threonine protein kinase of the secondmessenger subfamily. Proceedings of the National Academy of Sciences of the United States of America. 1991;88(10):4171-5.

79. Hanada M, Feng J, Hemmings BA. Structure, regulation and function of PKB/AKT--a major therapeutic target. Biochimica et biophysica acta. 2004;1697(1-2):3-16.

80. Masure S, Haefner B, Wesselink JJ, Hoefnagel E, Mortier E, Verhasselt $P$, et al. Molecular cloning, expression and characterization of the human serine/threonine kinase Akt-3. European journal of biochemistry / FEBS. 1999;265(1):353-60.

81. Santi SA, Lee $\mathrm{H}$. The Akt isoforms are present at distinct subcellular locations. American journal of physiology Cell physiology. 2010;298(3):C580-91. 82. Coffer PJ, Jin J, Woodgett JR. Protein kinase B (c-Akt): a multifunctional mediator of phosphatidylinositol 3-kinase activation. The Biochemical journal. 1998;335 ( Pt 1):1-13.

83. Alessi DR, Andjelkovic M, Caudwell B, Cron P, Morrice N, Cohen P, et al. Mechanism of activation of protein kinase $B$ by insulin and IGF-1. The EMBO journal. 1996;15(23):6541-51. 
84. Blume-Jensen $\mathrm{P}$, Hunter $\mathrm{T}$. Oncogenic kinase signalling. Nature. 2001;411(6835):355-65.

85. Martelli AM, Faenza I, Billi AM, Manzoli L, Evangelisti C, Fala F, et al. Intranuclear 3'-phosphoinositide metabolism and Akt signaling: new mechanisms for tumorigenesis and protection against apoptosis? Cellular signalling. 2006;18(8):1101-7.

86. Dillon RL, White DE, Muller WJ. The phosphatidyl inositol 3-kinase signaling network: implications for human breast cancer. Oncogene. 2007;26(9):1338-45.

87. Maddika S, Panigrahi S, Wiechec E, Wesselborg S, Fischer U, SchulzeOsthoff K, et al. Unscheduled Akt-triggered activation of cyclin-dependent kinase 2 as a key effector mechanism of apoptin's anticancer toxicity. Molecular and cellular biology. 2009;29(5):1235-48.

88. Nave BT, Ouwens M, Withers DJ, Alessi DR, Shepherd PR. Mammalian target of rapamycin is a direct target for protein kinase $\mathrm{B}$ : identification of a convergence point for opposing effects of insulin and amino-acid deficiency on protein translation. The Biochemical journal. 1999;344 Pt 2:427-31.

89. Martelli AM, Tabellini G, Bressanin D, Ognibene A, Goto K, Cocco L, et al. The emerging multiple roles of nuclear Akt. Biochimica et biophysica acta. 2012;1823(12):2168-78.

90. Mavrakis KJ, Zhu H, Silva RL, Mills JR, Teruya-Feldstein J, Lowe SW, et al. Tumorigenic activity and therapeutic inhibition of Rheb GTPase. Genes \& development. 2008;22(16):2178-88.

91. Wang L, Harris TE, Lawrence JC, Jr. Regulation of proline-rich Akt substrate of $40 \mathrm{kDa}$ (PRAS40) function by mammalian target of rapamycin complex 1 (mTORC1)-mediated phosphorylation. The Journal of biological chemistry. 2008;283(23):15619-27.

92. Sarbassov DD, Guertin DA, Ali SM, Sabatini DM. Phosphorylation and regulation of Akt/PKB by the rictor-mTOR complex. Science. 2005;307(5712):1098-101.

93. Datta SR, Dudek H, Tao X, Masters S, Fu H, Gotoh Y, et al. Akt phosphorylation of BAD couples survival signals to the cell-intrinsic death machinery. Cell. 1997;91(2):231-41.

94. Cardone MH, Roy N, Stennicke HR, Salvesen GS, Franke TF, Stanbridge $\mathrm{E}$, et al. Regulation of cell death protease caspase-9 by phosphorylation. Science. 1998;282(5392):1318-21.

95. Romashkova JA, Makarov SS. NF-kappaB is a target of AKT in antiapoptotic PDGF signalling. Nature. 1999;401(6748):86-90.

96. Oren M. Decision making by p53: life, death and cancer. Cell death and differentiation. 2003;10(4):431-42.

97. Mayo LD, Donner DB. A phosphatidylinositol 3-kinase/Akt pathway promotes translocation of Mdm2 from the cytoplasm to the nucleus. Proceedings of the National Academy of Sciences of the United States of America. 2001;98(20):11598-603.

98. Zhou BP, Liao Y, Xia W, Zou Y, Spohn B, Hung MC. HER-2/neu induces p53 ubiquitination via Akt-mediated MDM2 phosphorylation. Nature cell biology. 2001;3(11):973-82. 
99. Los M, Maddika S, Erb B, Schulze-Osthoff K. Switching Akt: from survival signaling to deadly response. BioEssays : news and reviews in molecular, cellular and developmental biology. 2009;31(5):492-5.

100. Osaki M, Oshimura M, Ito H. PI3K-Akt pathway: its functions and alterations in human cancer. Apoptosis : an international journal on programmed cell death. 2004;9(6):667-76.

101. Liang J, Zubovitz J, Petrocelli T, Kotchetkov R, Connor MK, Han K, et al. PKB/Akt phosphorylates p27, impairs nuclear import of p27 and opposes p27mediated G1 arrest. Nature medicine. 2002;8(10):1153-60.

102. Zhou BP, Liao Y, Xia W, Spohn B, Lee MH, Hung MC. Cytoplasmic localization of p21Cip1/WAF1 by Akt-induced phosphorylation in HER-2/neuoverexpressing cells. Nature cell biology. 2001;3(3):245-52.

103. Diehl JA, Cheng M, Roussel MF, Sherr CJ. Glycogen synthase kinase3beta regulates cyclin D1 proteolysis and subcellular localization. Genes \& development. 1998;12(22):3499-511.

104. Maddika S, Ande SR, Wiechec E, Hansen LL, Wesselborg S, Los M. Aktmediated phosphorylation of CDK2 regulates its dual role in cell cycle progression and apoptosis. Journal of cell science. 2008;121(Pt 7):979-88.

105. Virgilio L, Narducci MG, Isobe M, Billips LG, Cooper MD, Croce CM, et al. Identification of the TCL1 gene involved in T-cell malignancies. Proceedings of the National Academy of Sciences of the United States of America. 1994;91(26):12530-4.

106. Meldi L, Brickner JH. Compartmentalization of the nucleus. Trends in cell biology. 2011;21(12):701-8.

107. Borgatti P, Martelli AM, Tabellini G, Bellacosa A, Capitani S, Neri LM. Threonine 308 phosphorylated form of Akt translocates to the nucleus of PC12 cells under nerve growth factor stimulation and associates with the nuclear matrix protein nucleolin. Journal of cellular physiology. 2003;196(1):79-88.

108. Leinninger GM, Backus C, Uhler MD, Lentz SI, Feldman EL. Phosphatidylinositol 3-kinase and Akt effectors mediate insulin-like growth factor-I neuroprotection in dorsal root ganglia neurons. FASEB journal : official publication of the Federation of American Societies for Experimental Biology. 2004;18(13):1544-6.

109. Meier R, Alessi DR, Cron P, Andjelkovic M, Hemmings BA. Mitogenic activation, phosphorylation, and nuclear translocation of protein kinase Bbeta. The Journal of biological chemistry. 1997;272(48):30491-7.

110. Ouyang YB, Zhang XH, He QP, Wang GX, Siesjo BK, Hu BR. Differential phosphorylation at Ser473 and Thr308 of Akt-1 in rat brain following hypoglycemic coma. Brain research. 2000;876(1-2):191-5.

111. Gao M, Knipe DM. Distal protein sequences can affect the function of a nuclear localization signal. Molecular and cellular biology. 1992;12(3):1330-9.

112. Saji M, Vasko V, Kada F, Allbritton EH, Burman KD, Ringel MD. Akt1 contains a functional leucine-rich nuclear export sequence. Biochemical and biophysical research communications. 2005;332(1):167-73.

113. Xuan Nguyen TL, Choi JW, Lee SB, Ye K, Woo SD, Lee KH, et al. Akt phosphorylation is essential for nuclear translocation and retention in NGFstimulated PC12 cells. Biochemical and biophysical research communications. 2006;349(2):789-98. 
114. Pekarsky Y, Koval A, Hallas C, Bichi R, Tresini M, Malstrom S, et al. Tcl1 enhances Akt kinase activity and mediates its nuclear translocation. Proceedings of the National Academy of Sciences of the United States of America. 2000;97(7):3028-33.

115. Kunstle G, Laine J, Pierron G, Kagami Si S, Nakajima H, Hoh F, et al. Identification of Akt association and oligomerization domains of the Akt kinase coactivator TCL1. Molecular and cellular biology. 2002;22(5):1513-25.

116. Badve S, Collins NR, Bhat-Nakshatri P, Turbin D, Leung S, Thorat M, et al. Subcellular localization of activated AKT in estrogen receptor- and progesterone receptor-expressing breast cancers: potential clinical implications. The American journal of pathology. 2010;176(5):2139-49.

117. Fiorenza MT, Torcia S, Canterini S, Bevilacqua A, Narducci MG, Ragone $\mathrm{G}$, et al. TCL1 promotes blastomere proliferation through nuclear transfer, but not direct phosphorylation, of AKT/PKB in early mouse embryos. Cell death and differentiation. 2008;15(2):420-2.

118. Andjelkovic M, Alessi DR, Meier R, Fernandez A, Lamb NJ, Frech M, et al. Role of translocation in the activation and function of protein kinase $B$. The Journal of biological chemistry. 1997;272(50):31515-24.

119. Golgi C. Sulla struttura della sostanza grigia dell cervello. Gazz Med Lombarda. 1873(33):244-6.

120. Barbarella G, Melucci M, Sotgiu G. The Versatile Thiophene: An Overview of Recent Research on Thiophene-Based Materials. Advanced Materials. 2005;17(13):1581-93.

121. Aslund A, Sigurdson CJ, Klingstedt T, Grathwohl S, Bolmont T, Dickstein $\mathrm{DL}$, et al. Novel pentameric thiophene derivatives for in vitro and in vivo optical imaging of a plethora of protein aggregates in cerebral amyloidoses. ACS chemical biology. 2009;4(8):673-84.

122. Palama I, Di Maria F, Viola I, Fabiano E, Gigli G, Bettini C, et al. Live-cellpermeant thiophene fluorophores and cell-mediated formation of fluorescent fibrils. Journal of the American Chemical Society. 2011;133(44):17777-85.

123. Nilsson KP, Rydberg J, Baltzer L, Inganas O. Self-assembly of synthetic peptides control conformation and optical properties of a zwitterionic polythiophene derivative. Proceedings of the National Academy of Sciences of the United States of America. 2003;100(18):10170-4.

124. Capobianco ML, Barbarella G, Manetto A. Oligothiophenes as fluorescent markers for biological applications. Molecules. 2012;17(1):910-33.

125. Capobianco ML, Naldi M, Zambianchi M, Barbarella G. Oligothiophene phosphoramidites for oligonucleotide labelling. Tetrahedron Letters. 2005;46(47):8181-4.

126. Hammarstrom $P$, Simon R, Nystrom S, Konradsson P, Aslund A, Nilsson $\mathrm{KP}$. A fluorescent pentameric thiophene derivative detects in vitro-formed prefibrillar protein aggregates. Biochemistry. 2010;49(32):6838-45.

127. Nilsson KP, Joshi-Barr S, Winson O, Sigurdson CJ. Prion strain interactions are highly selective. The Journal of neuroscience : the official journal of the Society for Neuroscience. 2010;30(36):12094-102.

128. Sigurdson CJ, Nilsson KP, Hornemann S, Heikenwalder M, Manco G, Schwarz $\mathrm{P}$, et al. De novo generation of a transmissible spongiform 
encephalopathy by mouse transgenesis. Proceedings of the National Academy of Sciences of the United States of America. 2009;106(1):304-9.

129. Mahajan V, Klingstedt T, Simon R, Nilsson KP, Thueringer A, Kashofer K, et al. Cross beta-sheet conformation of keratin 8 is a specific feature of MalloryDenk bodies compared with other hepatocyte inclusions. Gastroenterology. 2011;141(3):1080-90 e1-7.

130. Duca M, Dozza B, Lucarelli E, Santi S, Di Giorgio A, Barbarella G. Fluorescent labeling of human mesenchymal stem cells by thiophene fluorophores conjugated to a lipophilic carrier. Chemical communications. 2010;46(42):7948-50.

131. Di Maria F, Palama IE, Baroncini M, Barbieri A, Bongini A, Bizzarri R, et al. Live cell cytoplasm staining and selective labeling of intracellular proteins by non-toxic cell-permeant thiophene fluorophores. Organic \& biomolecular chemistry. 2014;12(10):1603-10.

132. Lucey BP, Nelson-Rees WA, Hutchins GM. Henrietta Lacks, HeLa cells, and cell culture contamination. Archives of pathology \& laboratory medicine. 2009;133(9):1463-7.

133. Cree IA, Glaysher S, Harvey AL. Efficacy of anti-cancer agents in cell lines versus human primary tumour tissue. Current opinion in pharmacology. 2010;10(4):375-9.

134. Ferreira D, Adega F, Chaves R. The Importance of Cancer Cell Lines as in vitro Models in Cancer Methylome Analysis and Anticancer Drugs Testing2013 2013-03-13.

135. Mullis K, Faloona F, Scharf S, Saiki R, Horn G, Erlich H. Specific enzymatic amplification of DNA in vitro: the polymerase chain reaction. Cold Spring Harbor symposia on quantitative biology. 1986;51 Pt 1:263-73.

136. Ishmael FT, Stellato C. Principles and applications of polymerase chain reaction: basic science for the practicing physician. Annals of allergy, asthma \& immunology : official publication of the American College of Allergy, Asthma, \& Immunology. 2008;101(4):437-43.

137. Wittwer CT, Herrmann MG, Moss AA, Rasmussen RP. Continuous fluorescence monitoring of rapid cycle DNA amplification. BioTechniques. 1997;22(1):130-1, 4-8.

138. Heid CA, Stevens J, Livak KJ, Williams PM. Real time quantitative PCR. Genome research. 1996;6(10):986-94.

139. Buell GN, Wickens MP, Payvar F, Schimke RT. Synthesis of full length cDNAs from four partially purified oviduct mRNAs. The Journal of biological chemistry. 1978;253(7):2471-82.

140. Liu ZQ, Mahmood T, Yang PC. Western blot: technique, theory and trouble shooting. North American journal of medical sciences. 2014;6(3):160.

141. Beutner EH. Immunofluorescent Staining: The Fluorescent Antibody Method. Bacteriological reviews. 1961;25(1):49-76.

142. Berridge MV, Herst PM, Tan AS. Tetrazolium dyes as tools in cell biology: new insights into their cellular reduction. Biotechnology annual review. 2005;11:127-52.

143. Shin SI, Freedman VH, Risser R, Pollack R. Tumorigenicity of virustransformed cells in nude mice is correlated specifically with anchorage 
independent growth in vitro. Proceedings of the National Academy of Sciences of the United States of America. 1975;72(11):4435-9.

144. Fulwyler MJ. Electronic separation of biological cells by volume. Science. 1965;150(3698):910-1.

145. Kramer N, Walzl A, Unger C, Rosner M, Krupitza G, Hengstschlager M, et al. In vitro cell migration and invasion assays. Mutation research. 2013;752(1):10-24.

146. Watanabe S, Umehara H, Murayama K, Okabe M, Kimura T, Nakano T. Activation of Akt signaling is sufficient to maintain pluripotency in mouse and primate embryonic stem cells. Oncogene. 2006;25(19):2697-707.

147. Fischer KM, Din S, Gude N, Konstandin MH, Wu W, Quijada P, et al. Cardiac progenitor cell commitment is inhibited by nuclear Akt expression. Circulation research. 2011;108(8):960-70.

148. Evangelisti C, Ricci F, Tazzari P, Chiarini F, Battistelli M, Falcieri E, et al. Preclinical testing of the Akt inhibitor triciribine in T-cell acute lymphoblastic leukemia. Journal of cellular physiology. 2011;226(3):822-31.

149. Lin Y, Yang Y, Li W, Chen Q, Li J, Pan X, et al. Reciprocal regulation of Akt and Oct4 promotes the self-renewal and survival of embryonal carcinoma cells. Molecular cell. 2012;48(4):627-40.

150. Peltier J, Conway A, Keung AJ, Schaffer DV. Akt increases sox2 expression in adult hippocampal neural progenitor cells, but increased sox2 does not promote proliferation. Stem cells and development. 2011;20(7):1153-61.

151. Zhu J, Blenis J, Yuan J. Activation of PI3K/Akt and MAPK pathways regulates Myc-mediated transcription by phosphorylating and promoting the degradation of Mad1. Proceedings of the National Academy of Sciences of the United States of America. 2008;105(18):6584-9.

152. Tan S, Ng Y, James DE. Next-generation Akt inhibitors provide greater specificity: effects on glucose metabolism in adipocytes. The Biochemical journal. 2011;435(2):539-44.

153. Cummins JM, Velculescu VE. Implications of micro-RNA profiling for cancer diagnosis. Oncogene. 2006;25(46):6220-7.

154. Dalmay T, Edwards DR. MicroRNAs and the hallmarks of cancer. Oncogene. 2006;25(46):6170-5.

155. Tricoli JV, Jacobson JW. MicroRNA: Potential for Cancer Detection, Diagnosis, and Prognosis. Cancer research. 2007;67(10):4553-5.

156. Altomare DA, Khaled AR. Homeostasis and the importance for a balance between AKT/mTOR activity and intracellular signaling. Current medicinal chemistry. 2012;19(22):3748-62.

157. Davis NM, Sokolosky M, Stadelman K, Abrams SL, Libra M, Candido S, et al. Deregulation of the EGFR/PI3K/PTEN/Akt/mTORC1 pathway in breast cancer: possibilities for therapeutic intervention. Oncotarget. 2014;5(13):460350.

158. Jangamreddy JR, Jain MV, Hallbeck AL, Roberg K, Lotfi K, Los MJ. Glucose starvation-mediated inhibition of salinomycin induced autophagy amplifies cancer cell specific cell death. Oncotarget. 2015;6(12):10134-45.

159. Jain MV, Jangamreddy JR, Grabarek J, Schweizer F, Klonisch T, CieslarPobuda A, et al. Nuclear localized Akt enhances breast cancer stem-like cells 
through counter-regulation of p21(Waf1/Cip1) and p27(kip1). Cell cycle. 2015;14(13):2109-20.

160. Shin I, Yakes FM, Rojo F, Shin NY, Bakin AV, Baselga J, et al. PKB/Akt mediates cell-cycle progression by phosphorylation of p27(Kip1) at threonine 157 and modulation of its cellular localization. Nature medicine. 2002;8(10):1145-52.

161. Wang X, Trotman LC, Koppie T, Alimonti A, Chen Z, Gao Z, et al. NEDD41 is a proto-oncogenic ubiquitin ligase for PTEN. Cell. 2007;128(1):129-39.

162. Lian Z, Di Cristofano A. Class reunion: PTEN joins the nuclear crew. Oncogene. 2005;24(50):7394-400.

163. Martini M, De Santis MC, Braccini L, Gulluni F, Hirsch E. PI3K/AKT signaling pathway and cancer: an updated review. Ann Med. 2014;46(6):372-83. 164. Altomare DA, Testa JR. Perturbations of the AKT signaling pathway in human cancer. Oncogene. 2005;24(50):7455-64.

165. Croce CM. Causes and consequences of microRNA dysregulation in cancer. Nature reviews Genetics. 2009;10(10):704-14.

166. Bijur GN, Jope RS. Rapid accumulation of Akt in mitochondria following phosphatidylinositol 3-kinase activation. Journal of neurochemistry. 2003;87(6):1427-35.

167. Shiraishi I, Melendez J, Ahn Y, Skavdahl M, Murphy E, Welch S, et al. Nuclear targeting of Akt enhances kinase activity and survival of cardiomyocytes. Circulation research. 2004;94(7):884-91.

168. Chaabane W, User SD, El-Gazzah M, Jaksik R, Sajjadi E, RzeszowskaWolny J, et al. Autophagy, apoptosis, mitoptosis and necrosis: interdependence between those pathways and effects on cancer. Archivum immunologiae et therapiae experimentalis. 2013;61(1):43-58.

169. Ghavami S, Shojaei S, Yeganeh B, Ande SR, Jangamreddy JR, Mehrpour $\mathrm{M}$, et al. Autophagy and apoptosis dysfunction in neurodegenerative disorders. Progress in neurobiology. 2014;112:24-49. 


\section{Articles}

The articles associated with this thesis have been removed for copyright reasons. For more details about these see:

http://urn.kb.se/resolve?urn=urn:nbn:se:liu:diva-127477 